CARADDE: Jurnal Pengabdian Kepada Masyarakat
institute
$\begin{gathered}\text { https://journal.ilininstitute.com/index.php/caradde } \\ \text { Volume 1 | Nomor 1 | Agustus | } 2018 \\ \text { e-ISSN: 2621-7910 dan p-ISSN: 2621-7961 } \\ \text { DOI: } \underline{\text { https://doi.org/10.31960/caradde.v1i1.5 }}\end{gathered}$

\title{
Pelatihan Manajemen Kesekretariatan Bagi Pengurus Unit Kegiatan Mahasiswa (UKM) di Universitas Bengkulu
}

\author{
Citra Dewi ${ }^{1}$, Arifto Juniardi ${ }^{2}$, Rita Prima Bendriyanti ${ }^{3}$
}

$\begin{array}{ll}\text { Keywords : } & \text { Abstrak. Kegiatan ini bertujuan untuk meningkatkan } \\ \text { Manajemen; } & \text { kemampuan pengurus Unit Kegiatan Mahasiswa } \\ \text { kesekretariatan; } & \text { Universitas Bengkulu dalam bidang manajemen } \\ \text { unit kegiatan mahasiswa } & \begin{array}{l}\text { kesekretariatan. Metode yang dilakukan dalam bentuk } \\ \text { ceramah, diskusi, dan workshop. Adapun kegiatan yang }\end{array} \\ & \begin{array}{l}\text { dilakukan adalah: (1) memberikan pemahaman tentang } \\ \text { pentingnya pengelolaan kesekretarian yang baik dan }\end{array} \\ \text { Corespondensi Author } & \text { benar, (2) memberikan pemahaman tentang teknik surat } \\ { }^{123} \text { Manajemen Pendidikan, Pendidikan } & \begin{array}{l}\text { Olahraga, Manajemen Pendidikan } \\ \text { menyurat yang benar berdasarkan tata bahasa yang baku, }\end{array} \\ \text { Email: citravioleta04@unived.ac.id } & \text { dan (3) melakukan simulasi pembuatan program } \\ \text { FKIP Universitas Dehasen Bengkulu } & \text { kesekretariatan dari mulai perencanaan sampai evaluasi } \\ \text { J1. Meranti Raya No.32 Kota Bengkulu } & \text { serta simulasi pembuatan surat menyurat. Kegiatan ini } \\ & \text { diikuti oleh 75 orang perwakilan dari tiap-tiap pengurus } \\ \text { History Artikel } & \text { organisasi kemahasiswaaan di Universitas Bengkulu. } \\ \text { Received: Juli-2018; } & \text { Sebagian besar peserta telah memahami pengelolaan } \\ \text { Reviewed: Juli-2018 } & \text { kesekretarian dan teknik surat menyurat dengan baik dan } \\ \text { Accepted: } \text { Agustus-2018 } & \text { benar. } \\ \text { Published: Agustus-2108 } & \end{array}$

(c) (1) This work is licensed under a Creative Commons Attribution 4.0 International License

\section{PENDAHULUAN:}

Secara harfiah, mahasiswa adalah orang yang belajar di perguruan tinggi, baik di universitas, institut, maupun akademi. Menurut Kamus Bahasa Indonesia (2008), Mahasiswa mempunyai peranan penting dalam mewujudkan cita-cita pembangunan nasional, sementara itu Perguruan Tinggi merupakan lembaga pendidikan yang secara formal diserahi tugas dan tanggung jawab mempersiapkan mahasiswa sesuai dengan tujuan pendidikan tinggi. (Wulan dan Abdullah, 2014)

Mahasiswa merupakan anggota masyarakat yang mempunyai ciri-ciri tertentu, antara lain: a) Mempunyai kemampuan dan kesempatan untuk belajar di perguruan tinggi, sehingga dapat digolongkan sebagai kaum intelegensia. b) Karena kesempatan yang ada, mahasiswa diharapkan nantinya dapat bertindak sebagai pemimpin yang mampu dan terampil, baik sebagai pemimpin masyarakat ataupun dalam dunia kerja. c) Diharapkan dapat menjadi daya penggerak yang dinamis bagi proses modernisasi. d) Diharapkan dapat memasuki dunia kerja sebagai tenaga yang berkualitas dan profesional.

Organisasi Mahasiswa InternalKampus adalah Organisasi mahasiswa yang melekat pada pribadi kampus atau universitas, dan memiliki kedudukan resmi di lingkungan perguruan tinggi. Organisasi ini mendapat pendanaan kegiatan 
kemahasiswaan secara mandiri, dari pengelola perguruan tinggi dan atau dari Kementerian/Lembaga,Pemerintah dan non pemerintah untuk memajukan program kerja serta kemajuannya lainya. Bentuknya dapat berupa Ikatan Organisasi Mahasiswa, seperti Badan Eksekutif Mahasiswa (BEM), Senat Mahasiswa tingkat fakultas dan Himpunan mahasiwa jurusan(HMJ), Dan Para Ketua Tingkat. Kewenangan pengaturan sepenuhnya ada di tangan pemimpin perguruan tinggi yang dituangkan dalam Statuta (UU No. 12 Tahun 2012).

Salah satu elemen dalam kegiatankemahasiswaan adalah kesekretariatan atau populer dikenal sebagai tugas seorang sekretaris. Bidang yang satu ini sangat identik dengan hal-hal yang berbau administrasi, surat-menyurat dan hal-hal lain yang sering dianalogikan tugas juru ketik yang dengan mulianya mengurusi surat, arsip, membuat proposal, menyelesaikan laporan pertanggung jawaban dimana keseluruhan kegiatan tersebut adalah salah satu unsur penunjang pelaksanaan suatu kegiatan. Akan tetapi, faktanya saat ini antusiasme rekanrekan mahasiswa mulai menurun untuk terlibat dalam bidang ini dibandingkan dengan bidang-bidang kegiatan yang lainnya.Seorang mahasiswa sudah sepatutnya dituntut dapat mengembangkan keterampilan hal-hal yang bersifat administrasi yang bisa digunakan mahasiswa pasca mereka terjun ke dunia kerja. Tetapi sayangnya tidak setiap mahasiswa mempunyai kemampuan untuk itu. oleh karena itu perluadanya pelatihan kesekretariatan untuk para mahasiswa di UKM Universitas Bengkulu."Secara klasik, manajemen adalah ilmu atau seni tentang bagaimana menggunakan sumber daya secara efisien, efektif dan rasional untuk mencapai tujuan organisasi yang telah ditetapkan sebelumnya (Muninjaya, 2004)".

Istilah administrasi berasal dari kata latin "ad + ministered" yang mempunyai pengertian membantu, melayani, atau memenuhi. Administrasi (Administration atau Administratie) adalah rangkaian kegiatan penataan yang dilakukan oleh sekelompok orang melalui usaha kerjasama untuk mencapai tujuan tertentu.Dengan demikian dapat dipahami bahwa segala kegiatan yang diselenggarakan dalam administrasi kesekretariatan adalah berhubungan dengan rangkaian kegiatan penataan yang berfungsi sebagai unsur penunjang kelancaran untuk mencapai tujuan organisasi. Keseluruhan fungsi utama ketatausahaan tersebut haruslah dilaksanakan dalam suatu sistem yang telah disepakati bersama dalam suatu organisasi. Hal ini disebabkan prioritas betapa pentingnya peranan administrasi kesekretariatan dalam fungsi sebagai sumber informasi dan gambaran pertanggungjawaban kelak. Hendaknya juga dalam prakteknya kehidupan nyata suatu organisasi, kegiatan penunjang ini dilaksanakan dengan menerapkan prinsip efisien, efektif, rasional dan produktif."Administrasi adalah ilmu atau seni yang mempelajari kerjasama sekelompok orang dalam suatu organisasi untuk mencapai tujuan bersama (White)".Sedangkan Kesekretariatan dapat diartikan sebagai keseluruhan rangkaian kegiatan penataan terhadap pekerjaan perkantoran (suratmenyurat) dan tugas-tugas bantuan lainnya dalam rangka menunjang kelancaran pencapaian tujuan organisasi.

$$
\text { Oleh karena itu pengertian }
$$

Administrasi Kesekretariatan adalah keseluruhan proses pelaksanaan rangkaian kegiatan penataan terhadap pekerjaan perkantoran dan tugas-tugas bantuan lainnya, dalam rangka menunjang kelancaran pencapaian tujuan organisasi.Lazim pula diIndonesia bahwa penggunaan administrasi kesekretariatan dapat digantikan dengan kata ketatausahaan. Secara tidak langsung dalam kesuksesan perjalanan suatu organisasi sangat tergantung dari peran yang dilakoni oleh individu seorang Sekretaris beserta perangkat sumber daya kesekretariatannya. Seorang Sekretaris adalah aktor utama sebagai konseptor (Initiator) dalam dunia ketatausahaan dimana dalam melakukan kewajibannya haruslah didukung anggota kesekretariatan yang bertindak sebagai pekerja (Worker) dan memiliki fasilitas sekretariat organisasi atau teknologi penunjang lainnya.

Manajernen dibutuhkan oleh siapa saja yang bekerja bersama-sama dalam organisasi untuk mencapai suatu tujuan. Manusia dalam perjalananhidupnya selalu hidup berkelompok dan menjadi anggota organisasi, baik kecil maupun besar, seperti organisasi lembaga pendidikan, perusahaan, profesi, perkumpulan olah raga, militer, dan 
sebagainya. Walaupun visi, misi dan wujud organisasi itu berbeda-beda tetapi pada fungsi manajerial yang dijalankan mempunyai persamaan (universal) prinsip. Handoko, (2003: 6-7), mengatakan, ada tiga alasan utama yang diperlukan manajemen yaitu: (a) manajemen dibutuhkan untuk mencapai tujuan orgaganisasi maupun pribadi. b) manajemen dibutuhkan untuk menjaga keseimbangan antara tujuan-tujuan, sasaransasaran, dan kegiatan-kegiatan yang saling bertentangan dari pihak-pihak yang berkepentingan di dalam, dan pemerintah. c) manajemen diperlukan untuk mencapai hasil yang efektif dan efisien atau dengan kata lain tanpa menghabiskan banyak waktu dan tenaga.

Metode pengenalan dan pengajaran yang cenderung tidak interaktif, membuat proses interaksi serta belajar mengajar menjadi membosankan dan tidak menarik, mahasiswa menjadi tidak antusias mengikuti Kegiatan Organisasi. Maksud dilaksanakannya kegiatan ini adalah memberikan pengenalan dan pelatihan kepada para mahasiswa bagaimana mengelola organisasi yang menarik terkait tentang cara pembuatan surat yang baik dan benar,cara mengelola rapat dan ilmu tentang kesekretariatan lainnya. Secara umum kegiatan ini bertujuan untuk mensosialisasikan dan meningkatkan kemampuan serta pengetahuan para mahasiswa yang tergabung dalam Unit Kegiatan Mahasiswa Universitas Bengkulu dalam bidang pembelajaran kesekretariatan.ManfaatKegiatan Kegiatan pengabdian kepada masyarakat berupa teredukasinya mahasiswa di UKM UniversitasBengkulu dalam bidang pembelajaran kesekretariatan. Maka dari itu diharapkan dapat memberikan manfaat bagi berbagi pihak, yaitu: Pertama kepadapeserta, terjadi tukar informasi kepada masyarakat di bidang ilmu kesekretariatan. Hasil dari pelatihan tersebut dapat diterapkan dalam proses belajar mengajar. Kedua kepada tim pelaksana, terlaksananya salah satu kegiatan yang diwajibkan kepada dosen Perguruan Tinggi yaitu dharma ketiga dari Tri Dharma PerguruanTinggi. Di samping itu juga dapat menerapkan kegiatan laboratorium yang ada di lingkungan guna kepentingan masyarakat. Dengan adanya pelatihan ini , masing-masing pengurus organisasi mahasiswa yang ada di
Universitas Bengkulu melakukan perbaikan dalam sistem pengelolaan kesekretariatan untuk menciptakan organisasi yang baik secara administrative dan professional.

\section{METODE}

Metode yang digunakan dalam pelaksanaan kegiatan ini adalah ceramah, diskusi, dan demonstrasikerja pembuatan program kesekretariatan mulai dari perencanaan sampai pada tahap evaluasi dan pembuatan surat keluar dalam administrasi kesektretariatan. Materi yang disampaikan meliputi pengelolaan kesekretariatan dan tata cara pembuatan surat resmi. Adapun peserta pada kegiatan ini ada perwakilan pengurus unit kegiatan mahasiswa dan organisasi mahasiswa internal kampus seperti Himpunan Mahasiswa di tingkat Program Studi, Badan Eksekutif Mahasiswa tingkat Fakultas dan Universitas yang ada di lingkungan Universitas Bengkulu sebanyak 55 peserta yang hadir.

\section{HASIL DAN PEMBAHASAN}

Sasaran kegiatan ini adalah pengurus organisasi Unit Kegiatan Mahasiswa dan pengurus organisasi mahasiswa intra kampus seperti Himpunan Mahasiswa dan Badan Eksekutif Mahasiswa yang ada di lingkungan Universitas Bengkulu. Peserta pelatihan ini berjumlah 55 orang. Sedangkan waktu pelaksanaan pelatihan adalah 17 Februari 2018 bertempat di gedung A aula Universitas Bengkulu. Upaya pengabdian kepada masyarakat telah dilakukan berupa seminardengan berbagai materi khususnya menyangkut urgensi manajemen kesekretariatan dan pengelolaan surat resmi yang baik dan benar. Semua kegiatan dapat berjalan sesuai dengan jadwal acara yang telah disusun sebelumnya. Pelatihan ini rencananya diikuti oleh 35 orang peserta di berbagai mahasiswa di Universitas Bengkulu, baik untuk mahasiswa FKIP,FISIP,FMIPA dan lain-lain.Yang penting peserta merupakan wakil resmi dari Organisasi Kemahasiswaan. Semua peserta yang hadir adalah peserta yang telah mengkonfirmasikan kehadirannnya pada acara pelatihan, tetapi pada pelaksanaannya ada penambahan peserta sebanyak 20 sehingga jumlah peserta menjadi 55 orang. 
Caradde: Jurnal Pengabdian Kepada Masyarakat

Vol 1 No 1, Agustus 2018

Peserta pelatihan terlihat bersemangat dalam mengikuti setiap materi yang diberikan. Materi yang diberikan menjadi pengetahuan baru bagi peserta karena berkaitan langsung dengan tugas dan tanggung jawab peserta yang sebagian besar adalah pengurus organisasi pada bidang kesekretariatan. Peserta pelatihan juga terlibat aktif dalam proses pelatihan. Mereka antusia untuk bertanya mengenai hal hal yang kurang dipahami. Pada tahap simulasi pembutan program kesekretariatan dan surat menyurat, peserta pelatihan bersemangat dalam berdiskusi, memberikan ide, gagasan yang berkaitan dengn tugas yang diberikan pada saat simulasi.disamping itu kerjasama antar anggota tim dapat berlangsung dengan baik karena peserta bertanggungjawab atas tugas simulasi yang diberikan.Menurut Saiman (2002:31), sekretariat merupakan suatu tempat di mana terjadinya aktivitas kerja yang sifatnya tetap pada suatu kantor atau suatu tempat tertentu yang telah ditetapkan untuk mencapai tujuan bersama.Selanjutnya, menurut Saiman, Pengertian kesekretariatan adalah aktivitas yang dilakukan pada sekretariat, yakni menunjukkan tata kerja atau proses kerjanya sekretariat. Kesekretariatan bersifat aktif dan dinamis dalam kegiatan jasa-jasa perkantoran, terutama yang sangat berkaitan dengan proses administrasi.
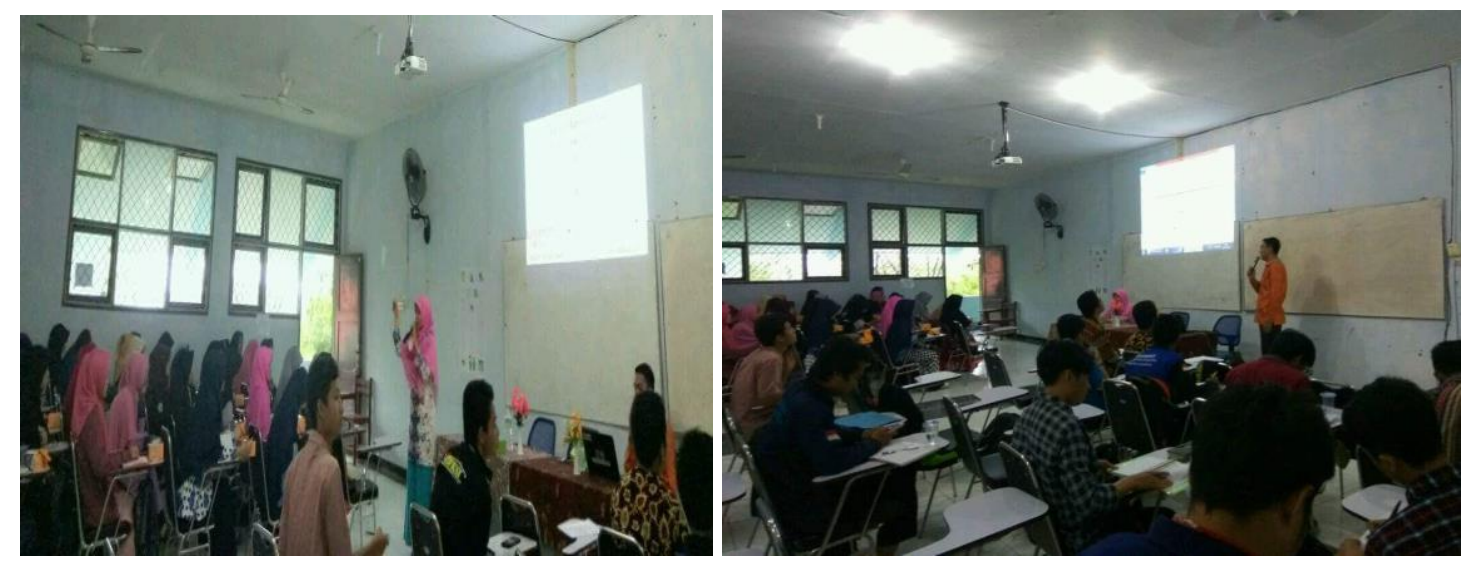

Gambar.1: Pemaparan Materi Dari Tim Pelaksana
Sekretaris organisasi adalah sekretaris yang bekerja atas perintah pimpinan, memiliki pula wewenang untuk turut membuat rencana, membuat keputusan, melakukan pengarahan dan pengkoordinasian terhadap seluruh unit yang ada dalam lingkungan. Tugas sekretaris organisasi adalah menjaga file yang tepat, baik untuk dokumen kertas penting dan juga untuk yang elektronik, menginformasikan kepada dewan direksi tentang pertemuan dan agendanya, mengirim laporan tahunan, mengedarkan surat tentang kebijakan perusahaan, dan rapat.Salah satu tanggung jawab utama seorang sekretaris organisasi adalah mengatur jadwal pertemuan sesuai dengan Perusahaan dan memastikan pertemuan secara efektif terorganisir. Selain itu menurut (Rosidah \& Ambar Teguh Sulistiyani, 2005:13-14) menjaga catatanadministrasi misalnya: menjaga rincian kontak up-to-date (yaitu nama, alamat dan nomor telepon) untuk komite manajemen dan anggota biasa dari organisasi, menyusun daftar nama dan alamat yang berguna untuk organisasi, termasul pejabat yang sesuai atau petugas dari organisasi sukarela, membuat catatan tentang kegiatan organisasi.Berikut disajikan dokumentasi kegiatan pelatihan manajemen kesekretariatan bagi organisasi mahasiswa di Universitas Bengkulu. 

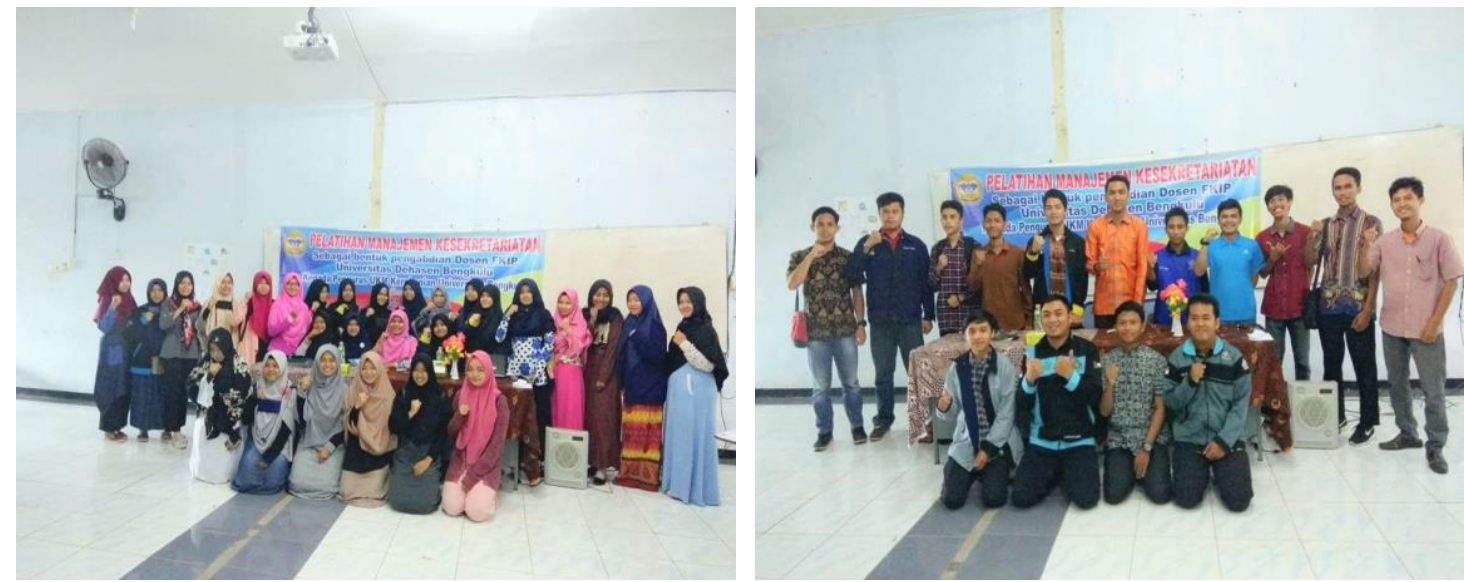

Gambar.2: Bersama Pemateri Dengan Para Peserta

Adapun hasil pelaksanaan pelatihan ini ada beberapa kendala yang dihadapi dalam pelaksanaan pelatihan manajemen kesekretariatan bagi pengurus organisasi kemahasiswaan di Universitas Bengkulu ini, yaitu (1) sarana dan prasarana penunjang kegiatan pelatihan yang belum memadai, sebagai contoh ruangan yang digunakan pelatihan menggunakan ruang kelas sementara jumlah peserta melebihi kapasitas ruangan yang disediakan, (2) beberapa pertanyaan dari peserta juga cenderung melebar kepada proses manajemen personil atau sumber daya manusia yang ada dalam organisasi masing-masing, (3) sebagian peserta mengeluhkan kesekretariatan yang dimilki tidak memdai untuk digunakan sebagai sekretariat. Tanggapan mereka atas persoalan tersebut mereka menginkan adanya perhatian yang lebih baik lagi kedepannya dalam rangka memenuhi sarana dan prasarana penunjang kegiatan kesekretariatan. Mereka seara umum juga sangat bahagia sekali dengan adanya kegiatan pelatihan semacam ini guna meningkatkan kapasitas mereka sebagai mahasiswa.

\section{SIMPULAN}

Dari hasil laporan ini dapat disimpulkan bahwa laporan pengabdian yang dilaksanakan diUKM Universitas Bengkulu dihadiri 55 orang yang tergabung dari berbagai prodi dan organisasi mahasiswa di lingkungan universitas Bengkulu. Para pemateri mensosialisasikan dan meningkatkan kemampuan serta pengetahuan para mahasiswa yang tergabung dalam UKM
Universitas Bengkulu dalam bidang manajemen kesekretariatan. Teredukasinya mahasiswa di UKM Universitas Bengkulu dalam bidang manajemen kesekretariatan maka diharapkan kedepan organisasi mahasiswa di lingkungan Universitas Bengkulu mampu mandiri dalam mengelola hal-hal yang berkaitan dengan surat-menyurat maupun manajemen rapat.

\section{DAFTAR PUSTAKA}

Ambar, Teguh Sulistiyani dan Rosidah, Manajemen Sumber Daya Manusia,(Yogyakarta : Graha Ilmu). 2009.

Dyah Ayu Noor Wulan dan Sri Muliati Abdullah,Prokrastinasi Akademik Dalam Penyelesaian Skripsi, (Yogyakarta :JurnalSosio-Huaniora : 2014)

Handoko, T.H. (2003). Manajemen, Yogyakarta, BPFE.

Kartono, Kartini. 2002. Psikologi Umum. Bandung : Sinar Baru Algies Indonesia

Muninjaya, A.A. Gde. (2004) Manajemen Kesehatan. Jakarta: Buku Kedokteran EGC.

RI. 2012. Undang- Undang RI No 12 Tahun 2012 Tentang Sistem Pendidikan Nasional. Jakarta:CV Eka Jaya.

Saiman. 2002. Manajemen Sekretaris. Jakarta :Ghalia Indonesia. 